\title{
High doses of vitamin A impair iron absorption
}

\author{
This article was published in the following Dove Press journal: \\ Nutrition and Dietary Supplements \\ 28 September 2012 \\ Number of times this article has been viewed
}

\section{Fabíola Rainato Gabriel Vivian MM Suen Julio Sergio Marchini José Eduardo Dutra de Oliveira}

Division of Clinical Nutrition, Department of Internal Medicine, Ribeirão Preto School of Medicine, São Paulo University, São Paulo, Brazil

Correspondence: Fabíola Rainato Gabriel Division of Clinical Nutrition, Department of Internal Medicine, Ribeirão Preto School of Medicine, São Paulo University Ribeirão Preto, São Paulo, Brazil

Tel +55 I6 36023375

Fax $+55 \quad 1636336695$

Email fabiolargm@yahoo.com.br
Objective: The present study aimed to determine the influence of vitamin A on iron absorption when vitamin A and iron are administered together orally compared with the administration of iron alone.

Methods: This was a randomized double-blind clinical trial conducted on healthy men with normal red blood cell indices. Five experiments were performed, with iron $(10 \mathrm{mg})$; iron $(10 \mathrm{mg})$ plus vitamin A (450, 900 and $1800 \mu \mathrm{g})$, and placebo. After an 8-hour fast, basal (T0) blood samples were collected: basal (T0), 2 hours (T1), and 4 hours (T2) after the ingestion of the compounds to be studied. Iron was determined by inductively coupled plasma mass spectrometry. Serum ferritin was determined by an immunometric method, ie, by chemoluminescent enzyme immunoassay. Plasma retinol was measured by high-pressure liquid chromatography. Serum curves and the sum of the area under the curve adjusted to the mixed effects linear model were determined $(P<0.05)$.

Results: Vitamin A at the doses of 450 and $900 \mu \mathrm{g}$ had a stimulating effect, which, however, did not differ significantly from that of experiment 1 in which iron was used alone. At the dose of $1800 \mu \mathrm{g}$, vitamin A had a negative effect on iron absorption.

Conclusion: High doses of vitamin A may cause lower serum iron levels, whereas a low dose favors iron absorption.

Keywords: iron absorption, serum iron, vitamin A, oral iron, oral supplement

\section{Introduction}

Iron absorption that occurs in the duodenum and upper jejunum ${ }^{1,2}$ may be affected by the action of agents that both stimulate and impair it. The interaction of vitamin $\mathrm{A}$ and iron was first shown in 1978 by Hodges et al, ${ }^{3}$ who suggested that a possible improvement of iron absorption occurred in the presence of vitamin A.

Martini et $\mathrm{al}^{4}$ observed increased iron availability in the presence of vitamin A. Regarding the participation of vitamin A in iron absorption, Strube et al ${ }^{5}$ suggested that vitamin A deficiency plays a decisive role in iron metabolism. Reduced transferrin synthesis, iron transport, and iron uptake by bone marrow resulted in inefficient erythropoiesis characterized by iron deficiency. In addition, studies have indicated the formation of an iron-vitamin A complex in the intestinal lumen as the factor responsible for the reduction of the inhibitory effects of both phytate and polyphenols on iron absorption. ${ }^{6}$

The objective of the present study was to determine the influence of vitamin A on iron absorption when the vitamin is administered orally with iron compared with the administration of iron alone. submit your manuscript $\mid$ www.dovepress.com

Dovepress

http://dx.doi.org/10.2147/NDS.S23608 
Table I Experiments performed with iron and vitamin A

\begin{tabular}{lll}
\hline Experiments & $\begin{array}{l}\text { Total iron } \\
(\mathbf{m g})\end{array}$ & $\begin{array}{l}\text { Vitamin A } \\
(\boldsymbol{\mu g})\end{array}$ \\
\hline $\mathrm{I}$ & 10 & - \\
$2 \mathrm{a}$ & 10 & 450 \\
$2 \mathrm{~b}$ & 10 & 900 \\
$2 \mathrm{c}$ & 10 & 1800 \\
3 & Placebo & - \\
\hline
\end{tabular}

Notes: I iron (10 mg); 2a iron (10 mg) and vitamin A (450 $\mu \mathrm{g}) ; 2 \mathrm{~b}$ iron (10 mg) and vitamin A $(900 \mu \mathrm{g}) ; 2 \mathrm{c}$ iron $(10 \mathrm{mg})$ and vitamin A iron (1800 $\mu \mathrm{g}) ; 3$ placebo.

\section{Materials and methods}

\section{Subjects}

This was a randomized, controlled, double-blind study conducted on healthy 19- to 30-year-old males with normal red blood cell índices and without anemia. Exclusion criteria were the following: practice of intense physical activity (more than 2 hours per day); diarrhea; use of medications; diseases of the stomach, pancreas, intestine, liver, and bile ducts; red blood cell levels below normal values; microcytosis and hypochromia; intestinal parasitosis; diabetes mellitus; arterial hypertension; renal insufficiency; obesity; smoking; and alcoholism.

Mean dietary iron ingestion by the volunteers was $17.1 \pm 5.1 \mathrm{mg}$ iron and $563.0 \pm 294.5 \mu \mathrm{g}$ vitamin A per day.

\section{Study design}

The randomization technique was used, and the subjects were distributed at random. Five experiments were carried out, as shown in Table 1.

After an 8-hour fast, basal blood samples were obtained from the volunteers for the determination of whole blood count, minerals (iron and calcium or zinc), ferritin, and vitamins $\mathrm{C}$ and $\mathrm{A}$ (Time 0 ).

Next, the volunteers received the compounds being tested accompanied by $200 \mathrm{~mL}$ water. They then fasted for an additional 4 hours for the monitoring of serum iron. Samples were collected at 2 (Time 1) and 4 hours (Time 2).

The presence of side effects, such as flatulence, eructation, gastric malaise, nausea, vomiting, intestinal colic, and diarrhea, was determined both at the end of the experiment and at 24 hours post-testing.

\section{Compounds}

Compounds used were ferrous sulfate and retinol palmitate.

\section{Biochemical parameters}

Using a vacuum aspiration system, blood samples were collected aseptically from a cubital vein into sterile tubes through a permanent catheter. For hemoglobin determination, blood was collected into Vacutainer ${ }^{\circledR}$ tubes (BD, Franklin Lakes, NJ) containing the anticoagulant ethylenediaminetetraacetic acid and sent to the Hematology Laboratory of HCFMRP-USP for analysis by the cyanomethemoglobin method using an automatic T890 or STKS counter (Beckman Coulter Inc, Pasadena, CA). Serum ferritin levels were determined with a DPC Immulite analyzer (Diagnostic Products Corporation, Los Angeles, CA) using an immunometric method (chemoluminescent enzymatic immunoassay) in the gynecology and obstetrics laboratory of HCFMRP-USP. Plasma Fe was measured by inductively coupled plasma mass spectrometry, using Palmer et al's method. ${ }^{7}$

Plasma retinol was measured by HPLC according to Arnaud et al's technique. ${ }^{8}$

\section{Statistical analysis}

Data were analyzed statistically based on the maximum serum iron concentration and on the sum of the areas under the curve by the trapezoid method. ${ }^{1}$

A mixed-effect linear model was used to compare mean serum iron levels between groups and the area under the

Table 2 Biochemical data for each experiment

\begin{tabular}{|c|c|c|c|c|c|c|c|}
\hline \multirow[t]{2}{*}{ Experiment } & \multirow[t]{2}{*}{$\mathbf{N}$} & \multicolumn{2}{|l|}{ HB } & \multicolumn{2}{|l|}{ FT } & \multicolumn{2}{|l|}{ SFe } \\
\hline & & Mean & $\begin{array}{l}\text { Standard } \\
\text { deviation }\end{array}$ & Mean & $\begin{array}{l}\text { Standard } \\
\text { deviation }\end{array}$ & Mean & $\begin{array}{l}\text { Standard } \\
\text { deviation }\end{array}$ \\
\hline I & 15 & 15.49 & 1.01 & 111.75 & 44.47 & 2.1 & 0.62 \\
\hline $2 a$ & 9 & 15.7 & 0.67 & 137.99 & 82.13 & 2.33 & 0.86 \\
\hline $2 b$ & 9 & 15.56 & 0.89 & 137.39 & 91.73 & 2.28 & 0.44 \\
\hline $2 c$ & 9 & 15.34 & 0.92 & 127.46 & 77.31 & 2.3 & 0.42 \\
\hline 3 & 14 & 15.56 & 1.02 & 110.46 & 74.19 & 2.28 & 0.82 \\
\hline
\end{tabular}

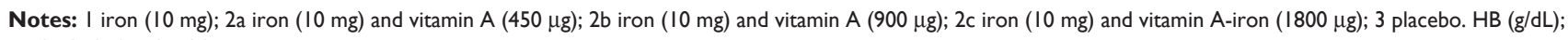
FT ( $\mu \mathrm{g} / \mathrm{dL}) ; \mathrm{SFe}(\mathrm{mg} / \mathrm{L})$.

Abbreviations: HB, hemoglobin; FT, serum ferritin; SFe, serum iron. 
Table 3 Comparison of the mean areas under the curve for the groups at basal time for the ferritin variable $(\mu \mathrm{g} / \mathrm{dL})$

\begin{tabular}{llll}
\hline Comparison & $\begin{array}{l}\text { Difference } \\
\text { between means }\end{array}$ & $\begin{array}{l}\text { Standard } \\
\text { error }\end{array}$ & P value \\
\hline I vs 2a & 14.17 & 9.89 & 0.16 \\
I vs 2b & 9.16 & 9.89 & 0.36 \\
I vs 2c & 12.68 & 9.89 & 0.20 \\
I vs 3 & 9.84 & 8.62 & 0.26 \\
2a vs 2b & -5.01 & 10.93 & 0.65 \\
2a vs 2c & -1.49 & 10.93 & 0.89 \\
2a vs 3 & -4.33 & 10.04 & 0.67 \\
2b vs 3 & 0.68 & 10.04 & 0.95 \\
2c vs 3 & -2.84 & 10.04 & 0.78 \\
2b vs 2c & 3.52 & 10.93 & 0.75 \\
\hline
\end{tabular}

Notes: I iron (10 mg); 2a iron (10 mg) and vitamin A ( $450 \mu \mathrm{g})$; $2 \mathrm{~b}$ iron (10 mg) and vitamin $\mathrm{A}(900 \mu \mathrm{g}) ; 2 \mathrm{c}$ iron $(10 \mathrm{mg})$ and vitamin $\mathrm{A}$ iron $(1800 \mu \mathrm{g}) ; 3$ placebo.

curve (AUC) at each time point with the level of significance set at $P<0.05$. $^{9}$

\section{Results and discussion}

Nine males with a mean age of $25.7 \pm 2$ years participated in the study. Mean height was $1.76 \pm 0.04 \mathrm{~cm}$ and mean weight was $79.28 \pm 15.24 \mathrm{~kg}$. Mean body mass index was $25.61 \pm 4.07 \mathrm{~kg} / \mathrm{m}^{2}$. The mean biochemical data for each day of the experiment are listed in Table 2.

To determine the interactions of micronutrients on iron absorption, we opted for the method of plasma monitoring. Hoppe et al, ${ }^{10,11}$ who validated the technique of serum iron monitoring, concluded that the method could determine the relative bioavailability of various iron compounds in relation to ferrous sulfate. Conway et $\mathrm{al}^{12}$ showed a good correlation between this method and the stable isotope technique for the determination of relative iron absorption from a meal. Plasma monitoring is relevant information regarding qualitative measurement, which provides comparisons of the experiments simultaneously when they are performed in the same individual - as by our group. ${ }^{13,14}$

In the present study, iron absorption in experiments $2 \mathrm{a}$ and $2 \mathrm{~b}$ was higher than in experiment $2 \mathrm{c}(P<0.05)$ regarding the monitoring of serum iron and the AUC. Iron absorption in experiment 1 was higher than in experiment $2 \mathrm{c}(P=0.04)$ and the AUC was greater in experiment 1 vs $2 \mathrm{c}(P=0.05)$. Thus, the results suggest that at the doses of 450 and $900 \mu \mathrm{g}$, vitamin A had a stimulating effect, which, however, did not differ significantly from that of experiment 1 in which iron was used alone. At the dose of $1800 \mu \mathrm{g}$, vitamin A had a negative effect on iron absorption.
Both the comparison of the mean AUCs for the groups at baseline for the time variable ferritin $(\mathrm{mg} / \mathrm{dL})$ and the comparison of the means for the groups with a fixed time for the standardized response variables are shown in Table 3. According to the baseline values (serum iron $\mathrm{mg} / \mathrm{dL}$ ) in Table 4 and Figure 1, the mean serum iron levels increased $(\mathrm{mg} / \mathrm{L})$ in experiments $1,2 \mathrm{a}, 2 \mathrm{~b}, 2 \mathrm{c}$, and 3 . The comparison of the AUCs for the variable serum iron $(\mathrm{mg} / \mathrm{L})$ is shown in Table 5.

In studies on isotopes, García-Casal et $\mathrm{al}^{15}$ showed that low doses of vitamin A or beta-carotene can double the absorption of nonheme iron in cereals by anemic adults, which is probably due to the prevention of the inhibitory effects of phytates on iron absorption. Studies have indicated that the formation of an iron-vitamin A complex in the intestinal lumen is responsible for the inhibitory effects of both phytate and polyphenols on iron absorption. ${ }^{6}$

However, Walczyk et a ${ }^{16}$ did not detect a change in iron absorption due to an effect of vitamin A, and stated that vitamin A possibly improves iron absorption in individuals with vitamin A deficiency. Studies evaluating the influence

Table 4 Comparison of the means for the groups with a fixed time for the response variables standardized according to the basal values (serum iron $[\mathrm{mg} / \mathrm{dL}]$ )

\begin{tabular}{|c|c|c|c|}
\hline & $\begin{array}{l}\text { Difference } \\
\text { between means }\end{array}$ & $\begin{array}{l}\text { Standard } \\
\text { error }\end{array}$ & $P$ value \\
\hline \multicolumn{4}{|c|}{ Comparison at time I } \\
\hline I vs 3 & 0.18 & 0.24 & 0.44 \\
\hline $2 a$ vs $2 b$ & 0.04 & 0.30 & 0.89 \\
\hline $2 a$ vs $2 c$ & 0.56 & 0.30 & 0.07 \\
\hline $2 a$ vs 3 & 0.31 & 0.28 & 0.27 \\
\hline $2 b$ vs $2 c$ & 0.52 & 0.30 & 0.09 \\
\hline $2 b$ vs 3 & 0.27 & 0.28 & 0.34 \\
\hline $2 c$ vs 3 & -0.25 & 0.28 & 0.36 \\
\hline I vs $2 a$ & -0.12 & 0.27 & 0.65 \\
\hline I vs $2 b$ & -0.08 & 0.27 & 0.76 \\
\hline I vs $2 c$ & 0.43 & 0.27 & 0.11 \\
\hline \multicolumn{4}{|c|}{ Comparison at time 2} \\
\hline I vs 3 & 0.41 & 0.24 & 0.08 \\
\hline $2 a$ vs $2 b$ & 0.31 & 0.30 & 0.31 \\
\hline $2 a$ vs $2 c$ & 0.93 & 0.30 & $<0.01$ \\
\hline $2 a$ vs 3 & 0.79 & 0.28 & $<0.01$ \\
\hline $2 b$ vs $2 c$ & 0.62 & 0.30 & 0.04 \\
\hline $2 b$ vs 3 & 0.48 & 0.28 & 0.08 \\
\hline $2 c$ vs 3 & -0.14 & 0.28 & 0.61 \\
\hline I vs $2 a$ & -0.37 & 0.27 & 0.17 \\
\hline I vs $2 b$ & -0.07 & 0.27 & 0.80 \\
\hline I vs $2 c$ & 0.56 & 0.27 & 0.04 \\
\hline
\end{tabular}

Notes: I iron (10 mg); 2a iron (10 mg) and vitamin A (450 $\mu \mathrm{g}) ; 2 \mathrm{~b}$ iron (10 mg) and

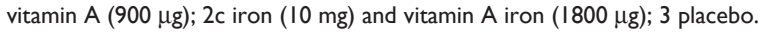




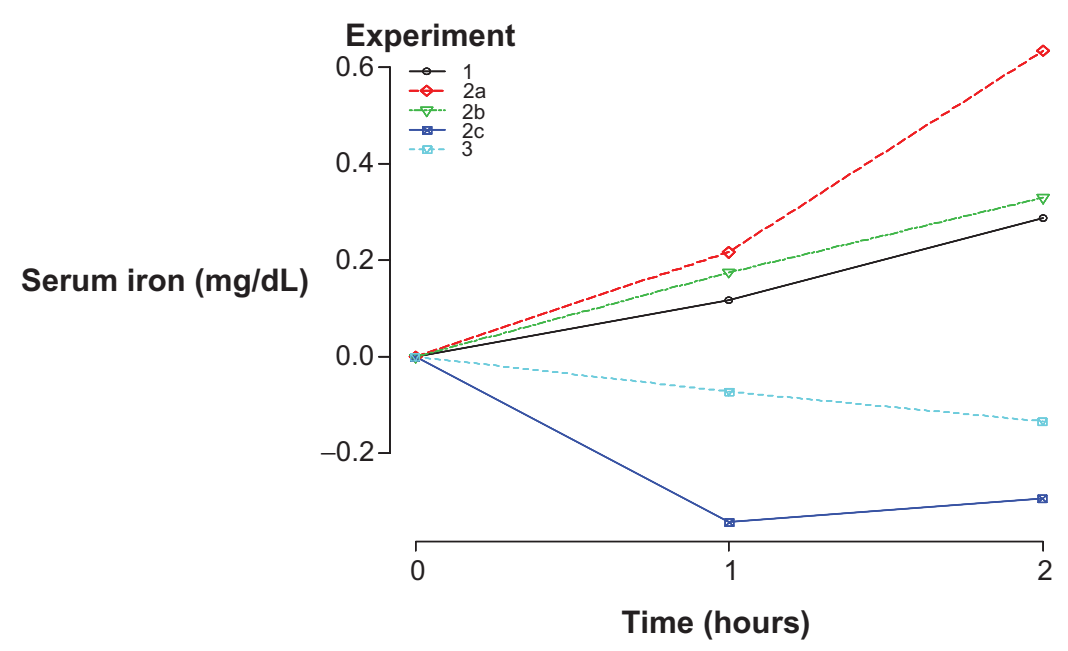

Figure I Mean serum iron increase $(\mathrm{mg} / \mathrm{L})$ in experiments I, 2a, 2b, 2c, and 3.

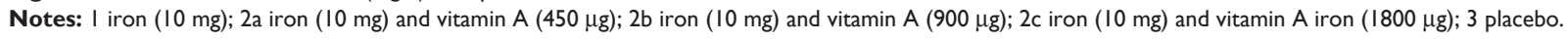

of vitamin A on iron absorption still present contradictory results. According to Davidsson et al, ${ }^{17}$ this conflicting information about the influence of vitamin A on improved iron absorption indicates the complexity of the interactions between vitamin A and iron metabolism.

Silva et al ${ }^{18}$ explored the relation between serum retinol levels and biochemical indicators of iron nutritional status in a population of children and adolescents in the Southwest region of Bahia. Their results indicated a positive and statistically significant association between serum retinol levels and hemoglobin levels $(P=0.007)$, serum iron levels $(P=0.010)$, and saturated transferring levels ( $\%$ TS $)(P=0.027)$.

The positive interaction between vitamin $\mathrm{A}$ and iron absorption was identified, although the mechanism by which this interaction occurs has not been fully elucidated. It is possible that vitamin A does not directly interfere with

Table 5 Comparison of the areas under the curve for the serum iron variable $(\mathrm{mg} / \mathrm{L})$

\begin{tabular}{llll}
\hline Comparison & $\begin{array}{l}\text { Difference } \\
\text { between means }\end{array}$ & $\begin{array}{l}\text { Standard } \\
\text { error }\end{array}$ & P value \\
\hline I vs 2a & -0.29 & 0.37 & 0.43 \\
I vs 2b & -0.09 & 0.37 & 0.80 \\
I vs 2c & 0.74 & 0.37 & 0.05 \\
I vs 3 & 0.40 & 0.32 & 0.22 \\
2a vs 2b & 0.20 & 0.41 & 0.63 \\
2a vs 2c & 1.03 & 0.41 & 0.01 \\
2a vs 3 & 0.68 & 0.37 & 0.07 \\
2b vs 2c & 0.83 & 0.41 & 0.04 \\
2b vs 3 & 0.49 & 0.37 & 0.19 \\
2c vs 3 & -0.34 & 0.37 & 0.36 \\
\hline
\end{tabular}

Notes: I iron (10 mg); 2a iron (10 mg) and vitamin A (450 $\mu \mathrm{g}) ; 2 \mathrm{~b}$ iron $(10 \mathrm{mg})$ and

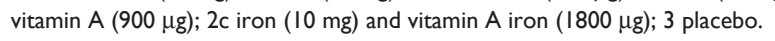

iron absorption in the intestinal tract but acts by mobilizing iron stores, thus rendering them available for hemoglobin formation. Another possible mechanism could be that vitamin A stimulates the synthesis of transferrin by increasing iron transport from plasma to the tissues. ${ }^{18,19}$

High doses of vitamin A may lead to lower serum iron levels, whereas low doses favor iron absorption. Thus, iron should always accompany physiological doses of vitamin A in order to stimulate iron absorption.

\section{Disclosure}

The authors report no conflicts of interest in this work.

\section{References}

1. Simovich M, Hainsworth LN, Fields PA, UmbreitJN, ConradME. Localization of the iron transport proteins Mobilferrin and DMT-1 in the duodenum: the surprising role of mucin. Am J Hematol. 2003;74(1):32-45.

2. Vaghefi N, Nedjaoum F, Guillochon D, Bureau F, Archan P, Bouglé D. Iron absorption from concentrated hemoglobin hydrolysate by rat. $J$ Nutr Biochem. 2005;16(6):347-352.

3. Hodges RE, Sauberlich HE, Canham JE, et al. Hematopoietic studies in vitamin A deficiency. Am J Clin Nutr. 1978;31:876-885.

4. Martini LA, Tchack L, Wood RJ. Iron treatment downregulates DMT1 and IREG1 mRNA expression in Caco-2 cells. J Nutr. 2002; 132(4):693-696.

5. Strube YN, Beard JL, Ross AC. Iron deficiency and marginal vitamin A deficiency affect growth, hematological indices and the regulation of iron metabolism genes in rats. J Nutr. 2002;132(12):3607-3615.

6. Layrisse M, García-Casal MN, Solano L, et al. The role of vitamin A on the inhibitors of nonheme iron absorption: Preliminary results. J Nutr Biochem. 1997;8(2):61-67.

7. Palmer CD, Lewis ME, Geraghty CM, Barbosa F, Parsons PJ. Determination of lead, cadmium and mercury in blood for assessment of environmental exposure: A comparison between inductively coupled plasma-mass spectrometry and atomic absorption spectrometry. Spectrochim Acta Part B At Spectrosc. 2006;61:980-990.

8. Arnaud J, Fortis I, Blachier S, Kia D, Favier A. Simultaneous determination of retinol, alpha-tocopherol and beta-carotene in serum by isocratic high-performance liquid chromatography. J Chromatogr. 1991;572(1-2):103-116. 
9. Molenberghs G, Verbeke G. Models for Discrete Longitudinal Data. Berlin, Germany: Springer; 2005.

10. Hoppe M, Hulthén L, Hallberg L. Serum iron concentration as a tool to measure relative iron absorption from elemental iron powders in man. Scand J Clin Lab Invest. 2003;63(7-8):489-496.

11. Hoppe M, Hulthén L, Hallberg L. The validation of using serum iron increase to measure iron absorption in human subjects. $\mathrm{Br} J$ Nutr. 2004;92(3):485-488.

12. Conway RE, Geissler CA, Hider RC, Thompson RPH, Powell JT. Serum iron curves can be used to estimate dietary iron bioavailability in humans. J Nutr. 2006;136(7):1910-1914.

13. da Silva LF, Dutra-de-Oliveira JE, Marchini JS. Serum iron analysis of adults receiving three different iron compounds. Nutr Res. 2004; 24(8):603-611.

14. Gabriel FR, Suen VM, Marchini JS, Dutra-de-Oliveira JE. Ingestion of ferrous sulfate increases ferremia in patients with short bowel syndrome. Nutrition. 2009;25(11-12):1115-1119.
15. García-Casal MN, Layrisse M, Solano L, et al. Vitamin A and betacarotene can improve nonheme iron absorption from rice, wheat and corn by humans. J Nutr. 1998;128(3):646-650.

16. Walczyk T, Davidsson L, Rossander-Hulthen L, Hallberg L, Hurrell RF. No enhancing effect of vitamin A on iron absorption in humans. Am J Clin Nutr. 2003;77(1):144-149.

17. Davidsson L, Adou P, Zeder C, Walczyk T, Hurrell R. The effect of retinyl palmitate added to iron-fortified maize porridge on erythrocyte incorporation of iron in African children with vitamin A deficiency. Br J Clin Nutr. 2003;90(2):337-343.

18. Staab DB, Hodges RE, Metcalf WK, Smith JL. Relationship between vitamin A and iron in the liver. $J$ Nutr. 1984;114(5):840-844.

19. Strube YN, Beard JL, Ross AC. Iron deficiency and marginal vitamin A deficiency affect growth, hematological, indices and the regulation of iron metabolism genes in rats. $J$ Nutr. 2002;132(12):3607-3615.
Nutrition and Dietary Supplements

\section{Publish your work in this journal}

Nutrition and Dietary Supplements is an international, peer-reviewed, open access journal focusing on research into nutritional requirements in health and disease, impact on metabolism and the identification and optimal use of dietary strategies and supplements necessary for normal growth and development. The journal welcomes papers covering

\section{Dovepress}

original research, basic science, clinical \& epidemiological studies, reviews and evaluations, guidelines, expert opinion and commentary, case reports and extended reports. The manuscript management system is completely online and includes a very quick and fair peer-review system, which is all easy to use.

Submit your manuscript here: http://www.dovepress.com/nutrition-and-dietary-supplements-journal 